medRxiv preprint doi: https://doi.org/10.1101/2021.10.05.21264551; this version posted October 7, 2021. The copyright holder for this preprint (which was not certified by peer review) is the author/funder, who has granted medRxiv a license to display the preprint in perpetuity.

It is made available under a CC-BY 4.0 International license.

\title{
1 Title: An assessment of a rapid SARS-CoV-2 antigen test in Bangladesh
}

2 Zannat Kawser ${ }^{1}$, Mohabbat Hossain ${ }^{1}$ Sara Suliman $^{2}$, Shahin Lockman ${ }^{3,4}$, Jesse Gitaka ${ }^{5,6}$, Gama

3 Bandawe $^{7}$, Redwan Rahmat $^{1}$, Imrul Hasan ${ }^{1}$, Abu Bakar Siddik ${ }^{1}$, Mokibul Hassan Afrad ${ }^{8}$,

4 Mohammed Ziaur Rahman ${ }^{8}$, Glenn Miller ${ }^{9}$, David R. Walt ${ }^{9,10,11}$, Louise C. Ivers ${ }^{12,13}$, Regina C.

5 LaRocque ${ }^{13}$, Jason B. Harris ${ }^{13}$, Firdausi Qadri, ${ }^{8^{*}}$

6 Email Adress:

7 Zannat Kawser- zannatzkawser@gmail.com

8 Mohabbat Hossain- mohabbat@ideshi.org

$9 \quad$ Sara Suliman- ssuliman1@ @wh.harvard.edu

10 Shahin Lockman- shahin.lockman@gmail.com

11 Jesse Gitaka-jgitaka@mku.ac.ke

12 Gama Bandawe- gbandawe@ must.ac.mw

13 Redwan Rahmat- redwan@ideshi.org

14 Mokibul Hassan Afrad- hassan.afrad@icddrb.org

15 Mohammed Ziaur Rahman-mzrahman@icddrb.org

16 Imrul Hasan-imrul@ideshi.org

17 Abu Bakar Siddik- absiddik@ideshi.org

18 Glenn Miller- GAMILLER@partners.org

19 David R. Walt-dwalt@bwh.harvard.edu 
medRxiv preprint doi: https://doi.org/10.1101/2021.10.05.21264551; this version posted October 7, 2021. The copyright holder for this preprint (which was not certified by peer review) is the author/funder, who has granted medRxiv a license to display the preprint in perpetuity.

It is made available under a CC-BY 4.0 International license .

21 Regina C. LaRocque- RCLAROCQUE@mgh.harvard.edu

22 Jason B. Harris- JBHARRIS@mgh.harvard.edu

$23 \quad$ Firdausi Qadri- fqadri@icddrb.org

\section{Author Affiliation:}

$25{ }^{1}$ institute for developing Science and Health initiatives (ideSHi), Dhaka, Bangladesh

$26 \quad{ }^{2}$ Infectious Disease Immunologist, Division of Experimental Medicine, Zuckerberg San

27 Francisco General Hospital, USA

$28{ }^{3}$ Division of Infectious Diseases, Brigham and Women's Hospital, Boston MA, USA

$29{ }^{4}$ Harvard T.H. Chan School of Public Health, Boston MA, USA

$30 \quad{ }^{5}$ Directorate of Research and Innovation, Mount Kenya University, Thika, Kenya

$31{ }^{6}$ Centre for Malaria Elimination, Mount Kenya University, Thika, Kenya

$32{ }^{7}$ Biological Sciences Department, Academy of Medical Sciences, Malawi University of Science

33 and Technology, Thyolo, Malawi

$34{ }^{8}$ International Center for Diarrheal Disease Research, Bangladesh (icddr,b), Dhaka, Bangladesh

$35{ }^{9}$ Mass General Brigham Center for COVID Innovation, Boston, MA

$36{ }^{10}$ Wyss Institute for Biologically Inspired Engineering, Harvard University, Boston, MA

$37{ }^{11}$ Department of Pathology, Brigham and Women's Hospital, Harvard Medical School, Boston, 38 MA

$39{ }^{12}$ Department of Global Health and Social Medicine, Harvard Medical School, Boston MA, $40 \quad$ USA

$41{ }^{13}$ MGH Center for Global Health, Massachusetts General Hospital, Boston MA, USA 
medRxiv preprint doi: https://doi.org/10.1101/2021.10.05.21264551; this version posted October 7, 2021. The copyright holder for this preprint (which was not certified by peer review) is the author/funder, who has granted medRxiv a license to display the preprint in perpetuity.

It is made available under a CC-BY 4.0 International license.

42

\section{$43 *$ Corresponding Author:}

$44 \quad$ Firdausi Qadri

45 Infectious Diseases Division (IDD), icddr,b, 68, Shaheed Tajuddin Ahmed Sarani, Mohakhali,

46 Dhaka 1212, Bangladesh

47 institute for developing Science and Health initiatives (ideSHi), 9 Mohakhali C/A, Dhaka 1212,

48 Bangladesh

49 Phone: 01711595367

50 email: fqadri@icddrb.org

51

52

53 Word count: 4195

54

55 Running head: Rapid SARS-CoV-2 antigen testing in Bangladesh

56 
medRxiv preprint doi: https://doi.org/10.1101/2021.10.05.21264551; this version posted October 7, 2021. The copyright holder for this preprint (which was not certified by peer review) is the author/funder, who has granted medRxiv a license to display the preprint in perpetuity.

It is made available under a CC-BY 4.0 International license .

Abstract (\# 249)

59 Early detection of SARS-CoV-2 infection is crucial to prevent the spread of the virus. In this study, we evaluated the performance of a commercial rapid antigen detection test, BD Veritor, and compared this (and another rapid test, Standard Q) against a gold-standard of nasopharyngeal (NP) swab tested by reverse transcription-polymerase chain reaction (RT-PCR) in prospectivelyrecruited adults in Dhaka, Bangladesh. We compared the sensitivity and specificity of the two rapid antigen tests against RT-PCR results in 130 symptomatic and 130 asymptomatic adults. In addition, we evaluated the suitability and ease-of-use of the BD Veritor test in a subsample of study participants $(n=42)$ and implementers $(n=5)$. The sensitivity of the BD Veritor rapid antigen test was $70 \%$ in symptomatic (95\% confidence interval [CI]: 51-85\%) and 87\% (95\% CI: 69-96\%) in asymptomatic individuals with positive SARSCoV-2 RT-PCR, for overall sensitivity of $78 \%$ (95\% CI: 66-88\%). The sensitivity of the Standard Q rapid antigen test was 63\% (95\% CI: 44$80 \%$ ) in symptomatic and $73 \%$ (95\% CI: 54-87\%) in asymptomatic individuals. One false positive

71 in BD Veritor test (specificity 99.5) and no false positive in Standard Q tests were observed

72 (specificity 100\%). The BD Veritor rapid antigen test was $78 \%$ sensitive when compared with

73 RT-PCR irrespective of the cycle threshold $(\mathrm{Ct})$ levels in this evaluation in Bangladesh. The 74 implementation evaluation data showed good acceptability in the field settings. This warrants large 75 field evaluation as well as use of the rapid antigen test for quick assessment of SARS-CoV-2 for containment of epidemics in the country.

77 Key Words: SARS-CoV-2, COVID-19, Rapid Antigen Test, RT-PCR, Implementation 78

\section{Introduction:}


medRxiv preprint doi: https://doi.org/10.1101/2021.10.05.21264551; this version posted October 7, 2021. The copyright holder for this preprint (which was not certified by peer review) is the author/funder, who has granted medRxiv a license to display the preprint in perpetuity.

It is made available under a CC-BY 4.0 International license .

Rapid antigen detection tests are point-of-care immunochromatographic assays which

81

82

83

84

85

86

87 detect protein antigens specific to the Severe Acute Respiratory Syndrome of the Coronavirus-2 (SARS-CoV-2) (e.g. nucleocapsid) (1). The ease-of-use and quick turnaround time of such tests can expand access to testing and decrease delays in diagnosis (2). Furthermore, modeling studies on SARS-CoV-2 have demonstrated that even if rapid antigen testing is associated with decreased sensitivity, the accessibility and short turnaround time in reporting results may be advantageous for decreasing transmission (3). Rapid antigen testing is particularly useful if deployed in the context of repeated testing over time (4) (5).

The performance of the rapid antigen tests has been determined by comparing their sensitivity and specificity with nucleic acid detection-based reference reaction (6). The current gold standard for identifying the presence of SARS-CoV-2 is reverse transcription-polymerase chain reaction (RT-PCR) in samples collected by nasopharyngeal (NP) swab (7). Despite their high sensitivity, nucleic acid amplification tests are associated with the need for laboratory processing, high costs, and a longer turnaround from sampling to return of results (8) (9). The NP swabs are also more challenging and uncomfortable (for patients) to collect than anterior nares swabs. For this reason, rapid antigen testing is a valuable tool for contact tracing and early detection of COVID-19 patients to triage for treatment options, especially in settings where RTPCR is less available or where follow-up reporting of RT-PCR results is more difficult, and particularly when anterior nares samples can be used.

In this study among asymptomatic and symptomatic adults, we evaluated the performance (sensitivity/specificity) of two rapid antigen detection tests, the BD Veritor ${ }^{\mathrm{TM}}$ (Becton-Dickenson, USA) and the Standard $\mathrm{Q}^{\mathrm{TM}}$ (SD-Biosensor, Korea) rapid antigen test, in comparison to NP swab RT-PCR as the reference standard. The BD Veritor was performed according to the manufacturer's 
medRxiv preprint doi: https://doi.org/10.1101/2021.10.05.21264551; this version posted October 7, 2021. The copyright holder for this preprint (which was not certified by peer review) is the author/funder, who has granted medRxiv a license to display the preprint in perpetuity.

It is made available under a CC-BY 4.0 International license .

recommendations using an anterior nares swab specimen, while the Standard Q and reference RTPCR were performed on nasopharyngeal swab specimens. We also evaluated the performance of the rapid antigen tests across the spectrum of RT-PCR cycle threshold $(\mathrm{Ct})$ values. Finally, we assessed the implementation characteristics of the BD Veritor rapid antigen test, including fitnessfor-use in different populations and settings in Bangladesh.

\section{Methodology:}

Study design and participants: We enrolled study participants at a triage and sample collection booth at Kurmitola General Hospital $(n=49)$ as well as at the ideSHi COVID-19 testing facility $(\mathrm{n}=211)$ in Dhaka, Bangladesh. Adults aged 18 and above were eligible for inclusion. For this analysis, we aimed to enroll 130 symptomatic patients with Covid-19 like symptoms including fever, cough, headache, sore throat, shortness of breath and fatigue (10) who had their onset of first symptom within five days, including 100 individuals with negative RT-PCR results and 30 individuals with positive RT-PCR results. In addition, we aimed for a similar target for positive and negative asymptomatic individuals who presented for routine COVID-19 screening at the above sites (primarily occupational screening or for known contact with an individual who tested positive). Written informed consent was obtained from participants. The study was approved by the Research Review Committee (RRC) and Ethical Review Committee (ERC) of icddr,b (Protocol no: PR- 20042).

Specimen collection: Nasopharyngeal swab specimens were collected by trained personnel and placed in a 3-mL tube of viral transport medium (Citoswab, Citotest Labware Manufacturing Co. Ltd, China) to be used for both Standard Q antigen testing and RT-PCR testing. Anterior nares 
medRxiv preprint doi: https://doi.org/10.1101/2021.10.05.21264551; this version posted October 7, 2021. The copyright holder for this preprint (which was not certified by peer review) is the author/funder, who has granted medRxiv a license to display the preprint in perpetuity.

It is made available under a CC-BY 4.0 International license .

125

126

127

128

129

130

131

132

133

134

135

136

137

138

139

140

141

142

143

144 the rnaseP housekeeping gene.

145

146

147 symptomatic and 30 asymptomatic).

swab samples were also collected by trained personnel according to the manufacturers' instructions for BD Veritor. Specifically, the swab provided with the kit was inserted into the anterior nasal cavity up to $2.5 \mathrm{~cm}$ and rolled 5 times along the mucosal surface in both nostrils.

The nasopharyngeal and anterior nares swab specimens were collected simultaneously until the first 200 individuals with negative RT-PCR results were enrolled in each group (100 symptomatic and 100 asymptomatic). Thereafter, the anterior nares samples were collected within 24 hours of the nasopharyngeal specimen until 60 individuals with positive RT-PCR results were accrued (30

RT-PCR on nasopharyngeal swab specimens: Viral RNA was extracted from 200 ul of viral transport media using the magnetic bead based Nexor 32 Fully Automated Nucleic Acid Extractor (Nucleic Acid Extraction or Purification Kit, Beijing Lepu Medical Technology Co., Ltd, China). RT-PCR was carried out using the China CDC primer and probes. In brief, this was performed in a $20 \mu$ reaction volume and each reaction contained extracted RNA, 2x iTaq Universal Probes Reaction Master Mix (Biorad, CA, USA), iScript Reverse Transcriptase, the CDC_ORF1ab and $\mathrm{N}$ forward and reverse primers, and probe (11)(12). Specimens were determined to be positive for SARS-CoV-2 when the ORF1ab and N genes were detected with an exponential growth curve and a cycle threshold $(\mathrm{Ct})$ value $<40$, and negative when these genes could not be detected. The test was considered positive even if one gene was detected. The quality of the nasopharyngeal specimen extracted was determined by analyzing the curve generated with

Rapid Antigen Testing: The rapid tests were performed in accordance with the manufacturer's instructions. For the BD Veritor assay, the anterior nares swab was inserted into the extraction reagent tube and mixed in the fluid for a minimum of 15 seconds before discarding. Three drops 
medRxiv preprint doi: https://doi.org/10.1101/2021.10.05.21264551; this version posted October 7, 2021. The copyright holder for this preprint (which was not certified by peer review) is the author/funder, who has granted medRxiv a license to display the preprint in perpetuity.

It is made available under a CC-BY 4.0 International license.

148 of the processed specimen were added to the sample well of the device, and incubated for 15

149 minutes. Following this, the test device was inserted into the Veritor Plus Analyzer (BD) for

150 reading.

For the Standard Q kit, $350 \mu \mathrm{L}$ of freshly obtained NP swab specimen in viral transport medium was reconstituted in the extraction buffer supplied by the manufacturer and incubated for 45-50 minutes. For testing, 3 drops (approximately $80 \mu \mathrm{L}$ ) of extracted nasopharyngeal specimen was applied to the sample well of device, and results were interpreted after 15 minutes, based on the manufacturer's instructions.

Assessment of implementation characteristics: We surveyed 5 test implementers and 42

157 participants about the BD Veritor test with a user acceptability and adoption assessment form for implementers and a feedback form for participants. Five point Likert scale was used for

159 documenting the level of satisfaction and level of difficulties in addition to the qualitative aspects in the questionnaire. We also assessed the BD Veritor test in comparison to NP swab RT-PCR regarding resources to collect and transport samples, and use of Personal Protective Equipment (PPE) and consumables. We evaluated turnaround times (from the sample collection time until the result was reported to the participant) for each sample type, assay, and platform from the time of collection to delivery of results.

Statistical analysis: We calculated the sensitivity and specificity (13) of each rapid test compared with the NP RT-PCR gold standard, and reported these as a percentage with $95 \%$ confidence intervals (CIs). The sensitivity of both rapid tests (combined) was also analyzed in RT-PCR 168 positive samples stratified by $\mathrm{Ct}$ value $>30,20-30$, and $<20$. The sensitivity of the two rapid tests was compared and $\mathrm{P}$ value was calculated using McNemar's Chi-Square Test. In addition, the 
medRxiv preprint doi: https://doi.org/10.1101/2021.10.05.21264551; this version posted October 7, 2021. The copyright holder for this preprint (which was not certified by peer review) is the author/funder, who has granted medRxiv a license to display the preprint in perpetuity.

It is made available under a CC-BY 4.0 International license .

comparison of $\mathrm{Ct}$ values between symptomatic and asymptomatic individuals was performed using the Mann-Whitney U test.

\section{Results:}

We enrolled 262 individuals in this study. Two study participants were subsequently excluded from the analysis because of incomplete information in the case record forms, resulting in a study set of 260 individuals. Forty-nine of the symptomatic individuals were enrolled at the Kurmitola General Hospital, while the remaining 211 participants included in the analysis were enrolled at the ideSHi testing facility. Demographic characteristics are shown in Table 1. The median age of the symptomatic individuals was 35 years (range, $18-81$ years), and 53\% were male. The most common symptom was fever $(\mathrm{N}=88,68 \%)$, and the median duration (and range) of symptoms were 3 days ( 1 to 5 days) in the symptomatic patients. The median age of the asymptomatic individuals was 33 years (range, $18-74$ ), and $81 \%$ were male.

The sensitivity and specificity of both rapid tests are reported in Table 2 . The sensitivity of the BD Veritor test (78\%) was higher than that of the Standard Q test $(68 \%)(\mathrm{P}=0.041)$. The sensitivity of both tests was higher in asymptomatic individuals than in symptomatic individuals.

Only one false positive BD Veritor test was identified in a screened symptomatic individual who reported a four-day history of cough with no fever, myalgia or loss of smell. No false positive Standard Q tests were observed.

We compared the performance of both rapid antigen tests stratified by the observed $\mathrm{Ct}$ value of the nasopharyngeal RT-PCR. There was no difference in the median Ct value between the symptomatic and asymptomatic individuals (Figure 1). We also observed no significant difference $(\mathrm{P}=0.2$ by Mann-Whitney $\mathrm{U}$ ) in the range of $\mathrm{Ct}$ values between the two groups and 
medRxiv preprint doi: https://doi.org/10.1101/2021.10.05.21264551; this version posted October 7, 2021. The copyright holder for this preprint (which was not certified by peer review) is the author/funder, who has granted medRxiv a license to display the preprint in perpetuity.

It is made available under a CC-BY 4.0 International license .

hence considered such individuals together in the analysis stratified by $\mathrm{Ct}$ value (Table 2). For RTPCR samples with a $\mathrm{Ct}<20$ (i.e., those with a high amount of viral genetic material), the sensitivity of both rapid antigen tests was $100 \%$. For RT-PCR samples with a $\mathrm{Ct}>30$ (i.e., those with little viral genetic material), neither rapid antigen test performed well (sensitivity <10\%). For RT-PCR samples with $\mathrm{Ct}$ values in the 20-30 range, the sensitivity of the BD Veritor test was 97\% (95\% CI: 84-100\%), compared with 81\% (95\% CI: 64-93\%) for the Standard Q.

We also interviewed a subgroup of participants $(n=42)$ within 24 hours after having obtained the anterior nares swab for the $\mathrm{BD}$ Veritor ${ }^{\mathrm{TM}}$ rapid test and asked them about the suitability of the test, the ease of the sample collection process, the ease of testing, the accuracy of the test and the turnaround time. Four participants were dissatisfied with the accuracy of the result by the BD Veritor ${ }^{\mathrm{TM}}$, while the remainder of the participants $(n=38)$ were satisfied. All of the 42 interviewees expressed satisfaction with the sample collection process, ease of testing and the 1520 minutes turnaround time. The 5 implementers surveyed, each of whom performed more than 50 tests, were satisfied with the kit components, the design of the device, the kit storage conditions, the quality controls, the time taken for the sequence of steps, the read-out of the results and the suitability for batch testing along with sequential testing. Based on their experience, testers estimated more than 100 patients could be tested and results given with the BD Veritor ${ }^{\mathrm{TM}}$ kit in one 8 hour period of a working day.

\section{Discussion:}

We evaluated the performance ofthe BD Veritor ${ }^{\mathrm{TM}}$ rapid antigen test and also compared with the Standard $\mathrm{Q}^{\mathrm{TM}}$ antigen test, for detecting SARS-CoV-2 in asymptomatic and symptomatic 
medRxiv preprint doi: https://doi.org/10.1101/2021.10.05.21264551; this version posted October 7, 2021. The copyright holder for this preprint (which was not certified by peer review) is the author/funder, who has granted medRxiv a license to display the preprint in perpetuity.

It is made available under a CC-BY 4.0 International license.

215

216

217

218

219

220

221

222

223

224

225

226

227

228

229

230

231

232

233

adults in a real-world, community-based study in Bangladesh between January to April 2021. We compared both tests to the gold standard RT-PCR performed on a nasopharyngeal swab. We found the BD Veritor test to be more sensitive (78\%) than the Standard Q $(68 \%)$ in our study population.

The sensitivity of both rapid antigen tests was highly dependent on the $\mathrm{Ct}$ value of the specimen evaluated. Both tests were $100 \%$ sensitive among individuals with $\mathrm{Ct}<20$ - those with high viral loads. These findings are consistent with a study in China that reported $68 \%$ sensitivity and $100 \%$ specificity when a Ct value $\leq 40$ was used as a cut off, as compared with $98 \%$ sensitivity and $100 \%$ specificity when $\mathrm{Ct}$ value $\leq 30$ (14).

Interestingly, we found that the sensitivity of both the rapid antigen tests was also high among asymptomatic individuals. . According to the RT-PCR analysis, the national prevalence rate of COVID-19 in Bangladesh during $26^{\text {th }}$ January-15 ${ }^{\text {th }}$ March ranged from 2 to $8 \%$ after which the rate increased to $24 \%$ and peaked by beginning of April 2021. Of note, most of the asymptomatic RT-PCR positive participants were enrolled during the period in which infections surged, while most of the symptomatic individuals were enrolled prior to the surge. Therefore the performance of rapid antigen might vary among population groups due to different epidemiological, geographical conditions and impact of the variants of concern (VOC) circulating in that time period although no difference has been found until now (5)(15). In Bangladesh, it was the UK variant, followed by the he South Africa variant predominating in Bangladesh at the time (https://www.gisaid.org/).

The use of anterior nares specimens for the BD Veritor rapid antigen test was an added advantage, and study participants found this test to be more acceptable than the nasopharyngeal swab. An additional advantage of the BD Veritor testing was that it was carried out directly at the study site and results were available immediately. In several instances, study participants were 
medRxiv preprint doi: https://doi.org/10.1101/2021.10.05.21264551; this version posted October 7, 2021. The copyright holder for this preprint (which was not certified by peer review) is the author/funder, who has granted medRxiv a license to display the preprint in perpetuity.

It is made available under a CC-BY 4.0 International license.

informed to isolate themselves until RT-PCR results confirmed the infection. In addition, the analyzer provided with the kit was able to detect very faint bands on the device barely visible by the naked eye which reduces the chance of human bias. Inclusion of the positive and negative controls with other kit components was helpful for quality assessment of the analyzer before use.

A limitation of our study is that we compared rapid antigen tests that required different types of clinical specimens: For the BD Veritor we used anterior nares specimens for rapid test and a NP sample for PCR; the Standard Q uses only one nasopharyngeal specimen, which is diluted in viral transport media and used for both PCR and rapid test. If the concentration of the virus differs between $\mathrm{AN}$ and NP swabs, that is in the two sites of the nostril, it can also affect results. However, we did not see significant discrepancies between the two tests, except when specimens had high RT-PCR Ct values, indicating low viral loads. In that case both BD Veritor and the Standard Q failed to detect SARS-CoV-2 virus. Notably, we also found the BD Veritor rapid antigen test to be more sensitive even though the anterior nares specimen for it were collected later for the RT-PCR positive individuals.

Our study on rapid antigen tests is timely for Bangladesh which is currently experiencing a second wave and high rates of COVID-19 (16). Point of care tests are urgently needed for health facilities, travelers, workplaces and the general population, and our findings can help guide the implementation of these tests in Bangladesh. The BD Veritor test is sensitive enough to detect cases with high viral load in pre-symptomatic and early symptomatic cases as well as asymptomatic persons - groups that likely contribute to a significant proportion of transmission and spread of the disease (17). The patients who test positive by rapid antigen tests can readily be diagnosed with a minimum turnaround time, which offers the opportunity for early interruption of transmission through targeted isolation and contact tracing, as infectivity may be high with a $\mathrm{Ct}<$ 
medRxiv preprint doi: https://doi.org/10.1101/2021.10.05.21264551; this version posted October 7, 2021. The copyright holder for this preprint (which was not certified by peer review) is the author/funder, who has granted medRxiv a license to display the preprint in perpetuity.

It is made available under a CC-BY 4.0 International license .

26124 or so (18). Persons with negative rapid test who are suspected of having COVID can be tested

262 by RT-PCR, depending on the epidemiologic context. Our information can provide

263 implementation guidance when deciding testing strategies in different settings.

264 Many countries are now planning the expanded use of rapid antigen tests, and our results

265 will provide guidance on their implementation in real-world settings such as that performed our

266 study site in Bangladesh. Rapid antigen tests will be a critical component of COVID-19 control

267 for the foreseeable future.

\section{Acknowledgment}

269 We gratefully acknowledge the support of Mass General Brigham (MGB) Center for COVID

270 Innovation for providing the BD Veritor plus analyzer antigen detection kits and the Massachusetts

271 General Hospital (MGH) for facilitation of the work. We thank the Bill and Melinda Gates

272 Foundation for support to icddr,b investigators. icddr,b is grateful to the Governments of

273 Bangladesh, Canada, Sweden, and the United Kingdom for providing core/unrestricted

274 support. The overall support of Fondation Merieux to ideSHi is acknowledeged. We would like to

275 express our gratitude to the participants for taking part and the field site staff of ideSHi for their

276 effort to accomplish the work. 
medRxiv preprint doi: https://doi.org/10.1101/2021.10.05.21264551; this version posted October 7, 2021. The copyright holder for this preprint (which was not certified by peer review) is the author/funder, who has granted medRxiv a license to display the preprint in perpetuity.

It is made available under a CC-BY 4.0 International license .

\section{References:}

1. Chaimayo C, Kaewnaphan B, Tanlieng N, Athipanyasilp N, Sirijatuphat R, Chayakulkeeree M, Angkasekwinai N, Sutthent R, Puangpunngam N, Tharmviboonsri T, Pongraweewan O, Chuthapisith S, Sirivatanauksorn Y, Kantakamalakul W, Horthongkham N. 2020. Rapid SARS-CoV-2 antigen detection assay in comparison with real-time RT-PCR assay for laboratory diagnosis of COVID-19 in Thailand. Virol J 17:1-7.

2. Eshghifar N, Busheri A, Shrestha R, Beqaj S. 2021. Evaluation of analytical performance of seven rapid antigen detection kits for detection of SARS-CoV-2 virus. Int J Gen Med $14: 435-440$.

3. Kennedy-Shaffer L, Baym M, Hanage WP. 2021. Perfect as the enemy of good: tracing transmissions with low-sensitivity tests to mitigate SARS-CoV-2 outbreaks. The Lancet Microbe 2:e219-e224.

4. Johansson MA, Wolford H, Paul P, Diaz PS, Chen TH, Brown CM, Cetron MS, AlvaradoRamy F. 2020. Reducing travel-related SARS-CoV-2 transmission with layered mitigation measures: Symptom monitoring, quarantine, and testing. medRxiv 1-13.

5. Holmdahl I, Kahn R, Hay JA, Buckee CO, Mina MJ. 2021. Estimation of Transmission of COVID-19 in Simulated Nursing Homes With Frequent Testing and Immunity-Based Staffing. JAMA Netw Open 4:e2110071.

6. WHO. 2020. Antigen-detection in the diagnosis of SARS-CoV-2 infection using rapid immunoassays Interim guidance, 11 September 2020. World Heal Organ 1-9.

7. Olalekan A, Iwalokun B, Akinloye OM, Popoola O, Samuel TA, Akinloye O. 2020. 
medRxiv preprint doi: https://doi.org/10.1101/2021.10.05.21264551; this version posted October 7, 2021. The copyright holder for this preprint (which was not certified by peer review) is the author/funder, who has granted medRxiv a license to display the preprint in perpetuity.

It is made available under a CC-BY 4.0 International license .

COVID-19 rapid diagnostic test could contain transmission in low- And middle-income countries. Afr J Lab Med 9:1-8.

8. Lambert-niclot S, Cuffel A, Pape L, Vauloup-fellous C, Morand-joubert L. 15635. Evaluation of a Rapid Diagnostic Assay for Detection of. J Clin Microbiol 58:e00977-20.

9. Udugama B, Kadhiresan P, Kozlowski HN, Malekjahani A, Osborne M, Li VYC, Chen H, Tools for Detection. ACS Nano 14:3822-3835.

10. Cascella M, Rajnik M, Aleem A, Dulebohn S, Di Napoli R. 2021. Features, evaluation, and treatment of coronavirus (COVID-19). StatPearls.

11. Jung Y, Park GS, Moon JH, Ku K, Beak SH, Lee CS, Kim S, Park EC, Park D, Lee JH,

Byeon CW, Lee JJ, Maeng JS, Kim SJ, Kim S Il, Kim BT, Lee MJ, Kim HG. 2020.

12. CDC. 2020. 2019-Novel Coronavirus ( 2019-nCoV ) Real-time rRT-PCR Panel Primers

14. Diao B, Wen K, Chen J, Liu Y, Yuan Z, Han C, Chen J, Pan Y, Chen L, Dan Y, Wang J, coronavirus 2 infection by detection of nucleocapsid protein. medRxiv https://doi.org/10.1101/2020.03.07.20032524. 
medRxiv preprint doi: https://doi.org/10.1101/2021.10.05.21264551; this version posted October 7, 2021. The copyright holder for this preprint (which was not certified by peer review) is the author/funder, who has granted medRxiv a license to display the preprint in perpetuity.

It is made available under a CC-BY 4.0 International license.

15. Saeed U, Uppal SR, Piracha ZZ, Rasheed A, Aftab Z, Zaheer H, Uppal R. 2021. Evaluation of SARS-CoV-2 antigen-based rapid diagnostic kits in Pakistan: formulation of COVID-19 national testing strategy. Virol J 18:1-5.

16. 2021. Experts: Bangladesh's second Covid wave has peaked, situation likely to improve in May. Dhaka Tribune.

17. ECDC. 2020. Options for the use of rapid antigen tests for COVID-19 in the EU/EEA and the UK.

18. Street L. 2016. Predicting infectious SARS-CoV-2 from diagnostic samples 306:0-19.

Tables.

Table 1: Demographic characteristics in different groups of participants.

\begin{tabular}{|l|c|c|c|c|}
\hline \multirow{2}{*}{ Characteristic } & \multicolumn{2}{c|}{ Symptomatic } & \multicolumn{2}{c|}{ Asymptomatic } \\
\cline { 2 - 5 } & PCR+(n=30) & PCR-(n=100) & PCR+(n=30) & PCR-(n=100) \\
\hline Median Age & 46.5 & 32 & 33.5 & 33 \\
\hline Sex & & & & \\
Male & $15(50 \%)$ & $54(54 \%)$ & $29(96 \%)$ & $76(76 \%)$ \\
Female & $15(50 \%)$ & $46(46 \%)$ & $1(4 \%)$ & $24(24 \%)$ \\
Population category & & & & $19(63.3 \%)$ \\
Student & $4(0 \%)$ & $0(0 \%)$ & $27(27 \%)$ \\
Healthcare worker & $3(10 \%)$ & $6(6 \%)$ & $0(0 \%)$ & $2(1 \%)$ \\
General population & $23(76.6 \%)$ & $75(75 \%)$ & $9(30 \%)$ & $70(70 \%)$ \\
\hline
\end{tabular}


medRxiv preprint doi: https://doi.org/10.1101/2021.10.05.21264551; this version posted October 7, 2021. The copyright holder for this preprint (which was not certified by peer review) is the author/funder, who has granted medRxiv a license to display the preprint in perpetuity.

It is made available under a CC-BY 4.0 International license .

\begin{tabular}{|l|c|c|c|c|}
\hline **Symptom spectrum & $1(3.3 \%)$ & $13(13 \%)$ & & \\
Fever alone & $4(13.3 \%)$ & $7(7 \%)$ & & \\
Fever+Cough & $0(0 \%)$ & $5(5 \%)$ & & \\
Fever+Headache & $5(16.7 \%)$ & $10(10 \%)$ & & \\
Fever+Cough+Headache & $7(23.3 \%)$ & $35(35 \%)$ & & \\
Symptoms without fever & $15(50 \%)$ & $43(43 \%)$ & $7(23.3 \%)$ & $3(3 \%)$ \\
\hline History of contact & $27(90 \%)$ & $89(89 \%)$ & $24(80 \%)$ & $97(97 \%)$ \\
\hline History of regular use of mask & & & \\
\hline
\end{tabular}

*Health care worker; **Other symptoms not mentioned indicate sore throat, shortness of breath,

diarrhea, loss of taste and/or loss of smell, generalized weakness

Table 2: Performance of two rapid antigen detection tests for detection of SARS-CoV-2 in comparison to nasopharyngeal RT-PCR.

\begin{tabular}{|c|c|c|c|c|c|c|c|}
\hline Category & & $\begin{array}{c}* \text { BD } \\
+ \\
(\mathbf{n})\end{array}$ & $\begin{array}{c}\text { BD } \\
- \\
(\mathbf{n})\end{array}$ & $\begin{array}{c}\text { BD } \\
\text { performance } \\
(95 \% \mathrm{CI})\end{array}$ & $\begin{array}{c}\text { *Standard } \\
\mathbf{Q}+ \\
(\mathbf{n})\end{array}$ & $\begin{array}{c}\text { Standard } \\
\text { Q- } \\
(\mathbf{n})\end{array}$ & $\begin{array}{c}\text { Standard Q } \\
\text { performance } \\
(95 \% \mathrm{CI})\end{array}$ \\
\hline \multirow[t]{2}{*}{ Symptomatic } & $\begin{array}{l}\mathrm{PCR}+ \\
(\mathrm{N}=30)\end{array}$ & 21 & 9 & $\begin{array}{c}\text { Sensitivity } \\
70 \% \\
(54-88 \%)\end{array}$ & 19 & 11 & $\begin{array}{c}\text { Sensitivity } \\
63 \% \\
(47-83 \%)\end{array}$ \\
\hline & $\begin{array}{c}\text { PCR - } \\
(\mathrm{N}=100)\end{array}$ & 1 & 99 & $\begin{array}{c}\text { Specificity } \\
99 \% \\
(95-100 \%)\end{array}$ & 0 & 100 & $\begin{array}{c}\text { Specificity } \\
100 \% \\
(69-100 \%) \\
\end{array}$ \\
\hline \multirow[t]{2}{*}{$\begin{array}{c}\text { Asymptomati } \\
\text { c }\end{array}$} & $\begin{array}{l}\mathrm{PCR}+ \\
(\mathrm{N}=30)\end{array}$ & 26 & 4 & $\begin{array}{c}\text { Sensitivity } \\
87 \% \\
(69-96 \%) \\
\end{array}$ & 22 & 8 & $\begin{array}{c}\text { Sensitivity } \\
73 \% \\
(61-92 \%) \\
\end{array}$ \\
\hline & $\begin{array}{c}\mathrm{PCR}- \\
(\mathrm{N}=100)\end{array}$ & 0 & 100 & $\begin{array}{c}\text { Specificity } \\
100 \% \\
(69-100 \%)\end{array}$ & 0 & 100 & $\begin{array}{c}\text { Specificity } \\
100 \% \\
(69-100 \%)\end{array}$ \\
\hline \multicolumn{8}{|c|}{ Overall sensitivity and specificity (both symptomatic and asymptomatic participants) } \\
\hline $\begin{array}{c}\text { Positive } \\
\text { PCR }\end{array}$ & $\mathrm{N}=60$ & 47 & 13 & $\begin{array}{c}\text { Sensitivity } \\
78 \% \\
(66-88 \%) \\
\end{array}$ & 41 & 19 & $\begin{array}{c}\text { Sensitivity } \\
68 \% \\
(55-80 \%) \\
\end{array}$ \\
\hline $\begin{array}{c}\text { Negative } \\
\text { PCR }\end{array}$ & $\begin{array}{c}\mathrm{N}= \\
(200)\end{array}$ & 1 & 199 & $\begin{array}{c}\text { Specificity } \\
99.5 \% \\
(97-100 \%)\end{array}$ & 0 & 200 & $\begin{array}{c}\text { Specificity } \\
100 \% \\
(98-100 \%)\end{array}$ \\
\hline
\end{tabular}

Combined symptomatic and asymptomatic categorized by RT-PCR cycle threshold (Ct) value 
medRxiv preprint doi: https://doi.org/10.1101/2021.10.05.21264551; this version posted October 7, 2021. The copyright holder for this preprint (which was not certified by peer review) is the author/funder, who has granted medRxiv a license to display the preprint in perpetuity.

It is made available under a CC-BY 4.0 International license.

\begin{tabular}{|c|c|c|c|c|c|c|c|}
\hline $\mathrm{Ct}>30$ & $\mathrm{~N}=13$ & 1 & 12 & $\begin{array}{c}\text { Sensitivity } \\
8 \% \\
(0-36 \%)\end{array}$ & 0 & 13 & $\begin{array}{c}\text { Sensitivity } \\
0 \% \\
(0-25 \%)\end{array}$ \\
\hline $\mathrm{Ct} 20-30$ & $\mathrm{~N}=32$ & 31 & 1 & $\begin{array}{c}\text { Sensitivity } \\
97 \% \\
(84-100 \%)\end{array}$ & 26 & 6 & $\begin{array}{c}\text { Sensitivity } \\
81 \% \\
(64-93 \%)\end{array}$ \\
\hline $\mathrm{Ct}<20$ & $\mathrm{~N}=15$ & 15 & 0 & $\begin{array}{c}\text { Sensitivity } \\
100 \% \\
(78-100 \%)\end{array}$ & 15 & 0 & $\begin{array}{c}\text { Sensitivity } \\
100 \% \\
(78-100 \%)\end{array}$ \\
\hline
\end{tabular}

$335 *$ For BD Veritor ${ }^{\mathrm{TM}}$ testing kit, anterior nares specimens and for Standard Q, nasopharyngeal

336 specimen were tested based on manufacturer's instruction.

337 Figures.

\section{Ct Value of RT-PCR vs. Rapid Test Results}

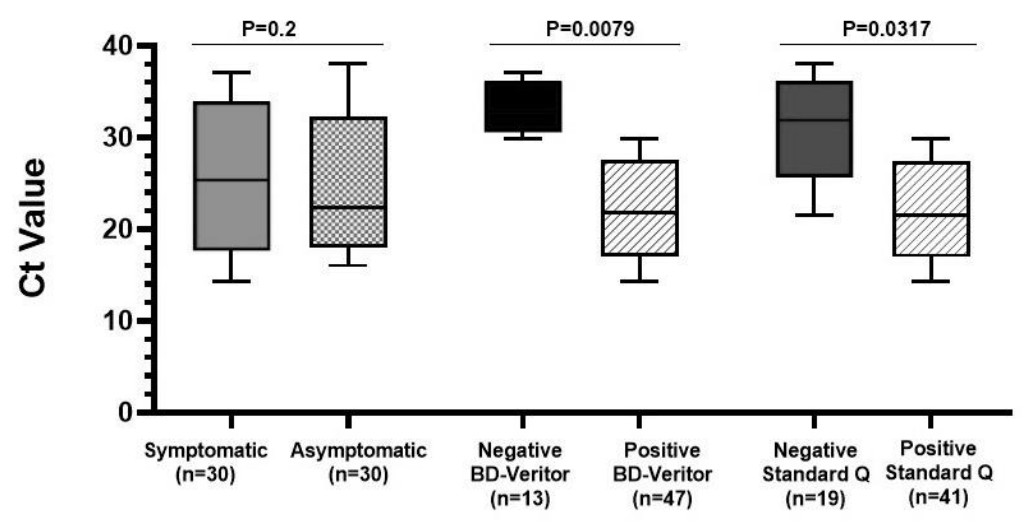

Figure 1. Comparison of $\mathrm{Ct}$ values among symptomatic and asymptomatic study

340 participants, and across rapid antigen tests. The was no significant difference in the median

$341 \mathrm{Ct}$ value in PCR positive symptomatic and asymptomatic participants, however, the median $\mathrm{Ct}$

342 values were significantly higher in individuals with false negative rapid antigen tests. 